\title{
The Influence of Microbial Community Dynamics on Anaerobic Digestion Efficiency and Stability: A Review
}

\author{
Yumechris Amekan*
}

\author{
Department of Biology, University of York, UK
}

\begin{abstract}
An essential component in sustainable energy development is the production of bioenergy from waste. The most successful bioenergy technology worldwide is anaerobic digestion (AD), which is a microbially-mediated process of organic feedstock conversion into energy-rich compounds (volatile fatty acids (VFA) and biogas) for renewable energy generation. AD is deployed in a range of situations including systems for on-farm energy recovery from animal and plant waste to the processing of food and municipal solid waste (with the additional benefit of land-fill reduction). Anaerobic digesters rely on a diverse microbial community working syntrophycally through a series of interrelated biochemical processes. Each stage in anaerobic digestion is carried out by different microbial groups. Thus, to optimise energy recovery from the $\mathrm{AD}$ process, the microbial community must have stable performance over time, balancing the various metabolic functions and taxonomic community composition in digesters. Complicating this balance, it has been found that the presence of ammonia, sulphate, and hydrogen sulphide in substantial concentrations often cause failure in the AD process. Thus, these substances cause adverse shifts in microbial community composition and/or inhibit bacterial growth, that influencing AD performance. $\mathbb{O} 2020$. CBIORE-IJRED. All rights reserved
\end{abstract}

Keywords: Biogas, Methane, Sustainable Energy, Anaerobic Digestion, Microbial community

Article History: Received: September 14, 2019; Revised: December 12, 2019; Accepted: January 16, 2020; Available online: February 15, 2020 How to Cite This Article: Amekan, Y., (2020) The influence of microbial community dynamics on anaerobic digestion efficiency and stability: A Review. International Journal of Renewable Energy Development, 9(1), 85-95.

https://doi.org/10.14710/ijred.9.1.85-95

\section{Anaerobic Digestion for Renewable Energy Generation in Indonesia}

Currently, the use of fossil fuels continues to increase globally reaching $88 \%$ of the total world energy needs (Bharathiraja et al. 2018). BP's Energy Outlook has even indicated that global energy demand will continue to grow to $35 \%$ by 2035 . In Indonesia, its economic growth rate $(5.05 \%$ in the first quarter of 2019; BPS - statistics Indonesia 2019) and population growth (1.10\% in 2019; BPS - statistic Indonesia 2019) increased the need for fossil fuels as the main energy source. The use of fossil energy reaches 94\% (Fig. 1; EBTKE 2016) of Indonesia's total energy consumption. This condition is exacerbated by the realization of reduced oil lifting making Indonesia a net oil importer (since 2003). High oil imports and the price of crude oil reaching $\$ 60 /$ barrel had a large impact on the trade balance.

Meanwhile, greater global political pressure to reduce carbon emissions occurred due to increasing amounts of greenhouse gas emissions (with carbon dioxide $\left(\mathrm{CO}_{2}\right)$ as the largest contributor) in the atmosphere as a result of burning fossil fuels. Indonesia's energy sector greenhouse gas emissions reached 261.89 million tons of $\mathrm{CO}_{2}$ produced mostly by electricity, transportation and industry. This value continues to increase by $2.43 \%$ per year over the range 2000-2015. This is caused by the growth in energy consumption which continues to grow $2.35 \%$ per year (EBTKE 2016).

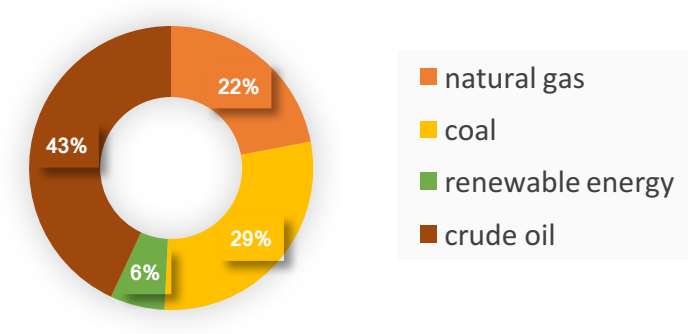

Fig 1. Indonesia's primary energy mix in 2015 (EBTKE 2016)

Also, the security of sustainable energy supply becomes a challenge in the global energy market because some oil and gas producing countries are in regions that are politically unstable and even experience military conflicts. Therefore, the utilization of alternative energy sources needs to be developed to ensure sustainable energy development, reduce dependence on fossil fuels and reduce adverse impacts on the environment.

Provision of alternative energy has become a concern of the Indonesian government through the issuance of Presidential Regulation No. 5 of 2006 concerning the

\footnotetext{
* Corresponding author: yumechris.amekan@gmail.com/ya611@york.ac.uk
} 
National Energy Policy to develop alternative energy sources as fuel substitutes for oil (Amekan and Guntoro 2017). New energy sources that are developed must be renewable, environmentally friendly and have high energy yields to minimize the use of fossil-based energy in the total primary energy mix (Zhang, $\mathrm{Hu}$ and Lee 2016; Amekan et al. 2018; Bharathiraja et al. 2018; NathiaNeves et al. 2018). Indonesia targets new renewable energy and bioenergy (biomass-based energy) to contribute $15 \%$ of the country's total energy needs and reduce emissions by $26 \%$ by 2020 (EBTKE 2016 ).

The latest data from the Directorate General of New, Renewable Energy and Energy Conversion (2016) shows that the energy potential so far has been utilized by the government including hydropower, solar, wind and marine energy. The amount of energy potentially produced is more than 300,000 MW. Energy supply generated from new renewable energy sources currently contributes significantly $(6.2 \%)$ which continues to increase (average 0.36\%/year) from the previous year, despite dependence on conventional fuels, such as gas, coal, and oil remains high (Figure 1). Therefore, the higher utilization of new renewable energy technologies is expected to play a role in the realization of reducing greenhouse gas emissions in Indonesia.

Another potential energy that Indonesia has also eyed in developing sustainable energy is the production of bioenergy from waste (animals, plants and domestic). One of the most successful bioenergy technologies throughout the world is anaerobic digestion (AD). The anaerobic digestion process involves microbes (bacteria and archaea) in the process of converting organic material under conditions without oxygen to produce biogas, especially methane, as an energy source for fuel and electricity (Werner et al. 2011; Vanwonterghem et al. 2014). AD can contribute to increasing the proportion of renewable energy based on biomass in Indonesia's total energy mix. This technology can also be a solution for processing waste materials which reaches 8 million tons per year with an energy potential of 534.73 MW (EBTKE 2016). Currently, there are more than 300 biogas reactors throughout Indonesia that include biomass-based power plant, biogas and municipal solid waste, Bioenergy power plant and household-scale biogas. This number is still far lower than Germany (the highest biogas producing country in Europe) which has more than 8000 active biogas reactors operating and the total biogas produced is equivalent to 4 TW (terawatt) electricity capacity (Achinas et al. 2017). Another example, in the United Kingdom (UK), the number of $\mathrm{AD}$ plants increasing almost $500 \%$ in 5 years (106 AD plants in 2013 to $607 \mathrm{AD}$ plants in 2018) according to a report from the Anaerobic Digestion \& Bioresources Association (ADBA). These biogas plants use various feedstock, like industrial, agricultural, municipal and sewage sludge feedstocks. The biogas production continues to experience rapid development despite global economic pressure and the biogas that now being produced is enough to power over 1 million homes in the UK.

\section{Conversion Steps in Anaerobic Digestion}

Biogas is a gaseous product (contains $50-80 \% \mathrm{CH}_{4}, 15$ $-45 \% \mathrm{CO}_{2}, 5 \% \mathrm{H}_{2} \mathrm{O}$ and some trace gases) that produced biologically through anaerobic digestion $(\mathrm{AD})$ process that involved diverse of microbial communities that work syntrophycally in supporting a series of interrelated biochemical reactions (Bond and Templeton 2011; Plugge 2017; Calusinska et al. 2018). Those four biochemical functions (Fig. 2; Heeg et al. 2014; Diaz et al. 2018) are (i) hydrolysis of complex polymers into simple soluble products, (ii) acidogenesis (fermentation of simple soluble products into short-chain fatty acids), (iii) acetogenesis (anaerobic oxidation of short-chain fatty acids/volatile fatty acids (VFAs) into acetates and hydrogen), and (iv) methanogenesis (methane production from acetate and hydrogen by methylotrophic/acetoclastic and hydrogenotrophic methanogens).

\subsection{Hydrolysis}

The complex substrates (polymers) that cannot be directly transported across the cell membrane of microorganisms, such as polysaccharides, lipids and proteins, are hydrolysed by hydrolases (cellulose, xylanase, pectinase, amylase, lipase, and protease) excreted by hydrolytic bacteria. Hydrolytic bacteria are very diverse phylogenetically. Many studies support findings that Firmicutes and Bacteroidetes although their abundance varies depending on operational conditions are the two dominant phyla in $\mathrm{AD}$ that responsible for the breakdown of the polymers, such as Acetivibrio, Clostridium, Bacteroides, and Thermotoga (Phylum Thermotogae), etc. (Liebl 2001; O'Sullivan et al. 2005; Cirne et al. 2007; Zverlov et al. 2010; Strauber et al. 2012; De Vrieze et al. 2015; Hassa et al. 2018). Hydrolytic bacteria have rapid growth and can utilise hydrolysis products as the growth substrate, mainly by fermentation which produces VFAs.

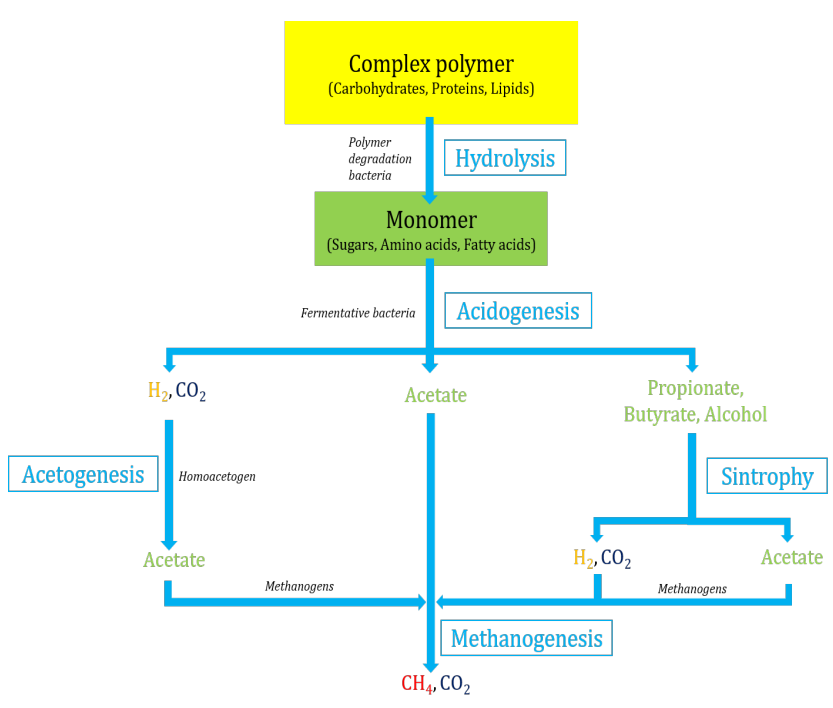

Fig 2. The interrelated biochemical functions in $\mathrm{AD}$ (adapted from Wirth et al. 2012).

\subsection{Acidogenesis and Acetogenesis}

Acidogenesis takes the hydrolytic products and ferments them, creating VFAs (such as acetate, propionate, butyrate, and valerate), carbon dioxide, hydrogen and ammonia. Acidogenic bacteria (acidogens) include hydrolytic bacteria and fermentation bacteria that do not produce extracellular hydrolases and are therefore reliant upon the hydrolytic bacteria for primary 
metabolites. Bacteroidetes, Chloroflexi, Firmicutes and Proteobacteria are dominant taxa that have many species of acidogens. There are a number of non-hydrolytic acidogens that successfully identified so far, including Bifidobacterium (phylum Actinobacteria), Anaerolinaceae (phylum Chloroflexi), and some thermophilic bacteria belonging to the Thermotogae phylum (Stiles and Holzapfel 1997; Balk et al. 2002; Dong et al. 2000; Yamada et al. 2006; De Vrieze et al. 2015). Acidogenesis progresses rapidly and can lead to VFA accumulation as well as a decrease in $\mathrm{pH}$ when given a substrate that is easily digested.

Some end products of hydrolysis and acidogenesis can be used directly by methanogens (acetoclastic and hydrogenotrophic) for biogas production, but other intermediates (such as VFAs and other simple alcohols) are metabolised and converted to the necessary substrates for methanogenesis (acetate, $\mathrm{CO}_{2}, \mathrm{H}_{2}$ ).

Syntrophic acetogenesis is the degradation/oxidation stages of intermediates into acetate, $\mathrm{H}_{2}$, and $\mathrm{CO}_{2}$. The term syntrophy referred to the symbiosis between acetogenic bacteria with hydrogenotrophic methanogens (de Bok et al. 2001). For example, acetogenesis carried out by Methanobacterium suboxydans (specializes in oxidizing 4-C and 6-C fatty acids to propionate and acetate), and Methanobacterium propionicum (convert propionate to acetate) will release hydrogen $\left(\mathrm{H}_{2}\right)$ that exhibit toxic effects to them, so it needs to be directly used by autotrophic methanogens (de Bok et al. 2005).

The oxidation of syntrophic propionate is significant because of almost $30 \%$ of the electrons generated from the complex substrate flow through propionate during the anaerobic digestion process (Speece et al. 2006). This stage is thermodynamically unfavourable unless the partial pressure of $\mathrm{H}_{2}$ is maintained below $10^{-4}$ atm (McCarty and Smith 1986; Lowe et al. 1993). In anaerobic digesters, hydrogenotrophic methanogens live near syntrophic acetogens and consume the hydrogen released. This syntrophic relationship is based on the transfer of hydrogen from the producing microbes to the hydrogen consumption, called interspecies hydrogen transfer (Boone 1985; Schink 1997; Stams and Plugge 2009), which keeps the $\mathrm{H}_{2}$ partial pressure low. Syntrophic acetogens found in anaerobic digesters include species in the genus Smithllela, Syntrophobacter, and Pelotomaculum for propionate oxidation (Liu et al. 1999; de Bok et al. 2001) and the genus Syntrophus and Syntrophomonas for the oxidation of butyric and longer chain fatty acids (Jackson et al. 1999; Imachi et al. 2007; Sousa et al. 2007). Syntrophic acetogenesis is a crucial step that determines the stability of anaerobic digester operations because some VFA, especially propionate, potentially inhibit methanogenesis even at neutral pH (Barredo and Evison 1991; Pullammanappallil et al. 1998; Demirel and Yenigün 2002; Nielsen et al. 2007). Moreover, the efficiency of biogas production depicted by acetogenesis (approximately $25 \%$ acetates and $11 \%$ of $\mathrm{H}_{2}$ is produced) because approximately $70 \%$ of $\mathrm{CH}_{4}$ generated through acetate reduction (Schink 1997).

\subsection{Methanogenesis}

Methanogenesis is an anaerobic metabolic stage responsible for methane formation. The final stage of anaerobic digestion is carried out by methanogens, commonly called methanoarchaea (phylogenetically belonging to the phylum Euryarchaeota), grouped into methylotrophic and hydrogenotrophic based on the substrates they use to form methane (Thauer et al. 2008). Hydrogenotrophic methanogens are represented by 5 orders (eg Methanomicrobiales, Methanospyrales, Methanocellales, Methanococcales, and Methanobacteriales) and almost all species depend on $\mathrm{CO}_{2}$ reduction to $\mathrm{CH}_{4}$. Hydrogen becomes the dominant compound of electron donors, but several other electron sources can also be used. Methylotrophic methanogen is represented by Methanosarcinales and Methanosaeta. Generally, species belonging to this group have characteristics capable of producing $\mathrm{CH}_{4}$ from various methyl compounds $\left(-\mathrm{CH}_{3}\right)$, or methyl groups on acetate. Hydrogenotrophic methanogens are believed to have lived since antiquity along with the emergence of life on earth, while methylotrophic methanogens began to develop over 500 million years ago (Fournier and Gogarten 2008; Liu et al. 2012; Sousa et al. 2013; Costa and Leigh 2014). Methanogens community changes (diversity and species richness) in the anaerobic digester is not affected by temperature or hydraulic retention time applied, but predominantly afflicted by the composition of the substrate/feedstock, availability of nutrients and ammonia/ammonium contents (Hassa et al. 2018).

The methanogenic pathway of all methanogenic species is essentially the same i.e. converting methyl groups into methane, but the only difference is the source of the methyl group they use as a source of carbon and energy. Most successfully isolated species can reduce $\mathrm{CO}_{2}$ to methyl by utilizing $\mathrm{H}_{2}$ or formic acid as a reducing agent. Some other species use $\mathrm{CO}$ and a small fraction utilizes short-chain alcoholic compounds as reducing agents (Guneratnam et al. 2017; Zabranska and Pokorna 2018). Other species obtain methyl groups directly from the substrate, such as acetate, methanol or methylamine. Although most isolates can reduce $\mathrm{CO}_{2}$, biologically only $30 \%$ of methane is obtained from this pathway. The majority $( \pm 70 \%)$ comes from converting methyl acetate groups into methane (Ferry 2002; Welte and Deppenmeier 2014).

\section{Effect of process parameters and inhibitory substances on microbial communities in the anaerobic digester}

Over the last decade, so many researches were conducted to help us understand the efficiency and stability of $\mathrm{AD}$ that relies on the syntrophic activity of diverse microorganisms performing hydrolysis, acidogenesis, acetogenesis and methanogenesis. Although $\mathrm{AD}$ has been subjected to substantial process engineering, the underpinning microbial community has been treated largely as a 'black box' and presents a significant opportunity for additional optimisation. Fortunately, rapid development in sequencing technology (nextgeneration sequencing (NGS)) that can provide more comprehensive information at a much cheaper cost, making it easier for researchers to identify and understand not only community composition and their metabolic functions but also how operational conditions (such as type of feedstock and temperature) influence microbial system (structure and dynamics) that can be linked to $\mathrm{AD}$ performance efficiency and stability (Talbot 
et al. 2008; Nelson, Morrison and Yu 2011; Wilkins et al. 2015; Bocher et al. 2015; De Vrieze et al. 2017; De Vrieze et al. 2018; Kirkegaard et al. 2017; Hardegen et al. 2018).

Each stage in anaerobic digestion is carried out by different microbial groups, and its composition in the consortium depends on several factors, such as the type of substrate, temperature, $\mathrm{pH}$, mixing and applied digester geometry (Yu and Mohan 2001; Insam et al. 2010; Francisci et al. 2015; Nathia-Neves et al. 2018). Therefore, to maintain process stability, it is crucial to keep the balance between the acid and methane forming microorganisms to optimising methane generation from the AD process. Previous studies also demonstrated that the presence of inhibitory substances in substantial concentrations (such as sodium chloride (Zhao et al. 2017), ammonia (Siles et al. 2010), sulphate (Siles et al. 2010), hydrogen sulphide (Hilton and Archer 1988), heavy metals (Dokulilova et al. 2018), and some organic compounds (Chen et al. 2008)) often cause failure in AD process. The inhibitors causing adverse shifts in microbial community composition and/or inhibit bacterial growth that influences AD performance.

\subsection{Temperature}

There are three major temperature operating ranges applied in anaerobic digester: psychrophilic $\left(4-15{ }^{\circ} \mathrm{C}\right)$, mesophilic $\left(20-40{ }^{\circ} \mathrm{C}\right)$ and thermophilic $\left(45-70{ }^{\circ} \mathrm{C}\right)(\mathrm{Kim}$ et al. 2017; Nathia-Neves et al. 2018). The operational temperature has a strong effect on the microbial communities involved in $\mathrm{AD}$ which results in huge differences in the types and abundance of microbes carrying out the process (De Vrieze et al. 2015; Kirkegaard et al. 2017). Temperature also affects the reaction thermodynamics, which the high temperature will favour oxidative reactions (i.e. acetate oxidation) while homoacetogenesis becomes more favourable at psychrophilic temperature (van Lier 1995; Schnurer et al. 1999).

\section{$3.2 \mathrm{pH}$}

Changes in $\mathrm{pH}$ can disrupt cell homeostasis and affects the microbial communities severely (Chen et al. 2008). Hydrolysis can be inhibited at either low or high $\mathrm{pH}$ because of the enzyme denaturation (Boon 1994). Hydrolytic bacteria and acidogens can tolerate the changes in $\mathrm{pH}$, but acetogens and methanogens cannot (Amani et al. 2010; Nathia-Neves et al. 2018). The free acids (associated organic acids, $\mathrm{H}_{2} \mathrm{~S}$ ) cause inhibition at lower $\mathrm{pH}$, and free bases $\left(\mathrm{NH}_{3}\right)$ cause inhibition at higher $\mathrm{pH}$ values. It causes a change in $\mathrm{pH}$ then affect the passive transport of the free acid or base across the cell membrane and subsequent dissociation which later leads to process imbalance (Henderson 1971; Gerardi 2003). The organisms that mostly affected by this inhibition are methanogens (acetoclastic and hydrogenotrophic) and syntrophic acetogens in the digester (Regueiro et al. 2014; Montanes et al. 2014; de Jonge et al. 2017).

\subsection{Ammonia $\left(\mathrm{NH}_{3}\right)$}

Ammonia generated during breakdowns of nitrogenrich organic feedstocks and can cause inhibition to the anaerobic digestion process through passive diffusion into the microorganism cell then induce proton imbalance and/or potassium deficiency (Kroeker et al. 1979; de Baere et al. 1984; Gallert et al. 1998). Some researcher has proposed the mechanism of ammonia inhibition, such as the change in the intracellular $\mathrm{pH}$, increase of maintenance energy requirements, and inhibition of specific enzyme reaction (Whittman et al. 1995; Rajagopal et al. 2013).

Ammonia is known as an essential substance for anaerobic microorganism growth if the concentration $50-$ $200 \mathrm{mg} / \mathrm{L}$ (McCarty 1964; Liu and Sung 2002), but if the concentration reaches $1.7-14 \mathrm{~g} / \mathrm{L}$ can caused $50 \%$ reduction in methane production (Sung and Liu 2003; Chen et al. 2008; Chen et al. 2016). The toxicity effect increases as the $\mathrm{pH}$ increase (Borja et al. 1996) because the high ratio of ammonium was shifting to its ionised form at higher $\mathrm{pH}$ when the concentration $1.5-3.0 \mathrm{~g} / \mathrm{L}$ (Angelidaki and Ahring 1993). If the amount of ammonia exceeds, $3.0 \mathrm{~g} / \mathrm{L}$ will cause complete inhibition of the $\mathrm{AD}$ process at any $\mathrm{pH}$ (Prochazka et al. 2012).

Methanogens are the most susceptible group of microorganism due to ammonia inhibition because other groups irrelevant with methanogenesis were enriched as a consequence of ammonia concentration increasing (Chen et al. 2016). Galert et al. (1998) have proposed two mechanisms of ammonia inhibition against methanogens, i.e. direct inhibition on methane-producing enzyme and inducing proton imbalance or potassium deficiency through passive diffusion of hydrophobic ammonia into the cell. According to Koster and Letinga (1988), 56.5\% of methanogens lost their activity, and acidogenic bacteria in the granular sludge get severe impact when the concentration of ammonia $4.05-5.73 \mathrm{~g} \quad \mathrm{NH}_{3} \mathrm{~N} / \mathrm{L}$. Methanospirillum hungatei is the most sensitive methanogens because it is being inhibited at $4.2 \mathrm{~g} \mathrm{NH}_{3}-$ N/L, while Methanosarcina barkeri, Methanobacterium thermoautotrophicum, and Methanobacterium formicicum were inhibited at $10 \mathrm{~g} \mathrm{NH}_{3}-\mathrm{N} / \mathrm{L}$ (Jarrell et al. 1987; Chen et al. 2008). Chen et al. (2016) show that the hydrogenotrophic methanogens (Methanobacterium and Methanospirillum) were inhibited when the ammonia concentrations exceed $6 \mathrm{~g} / \mathrm{L}$. Moreover, it was found that increasing ammonia concentration caused a shift in the methane production process from acetoclastic methanogenesis towards syntrophic acetate oxidation paired with hydrogenotrophic methanogenesis (Chen et al. 2016).

\subsection{Sulphate and Sulphide}

High levels of sulphate present in the feedstock can cause inhibition to the generation of methane from anaerobic digestion systems. The inhibition occurs because of sulphate reduction always predominates methane production in anaerobic digester treating sulphate-rich feedstock as a consequence of thermodynamic and kinetic differences between the two processes (Abram and Nedwell 1978). Sulphate favours the growth and metabolism of sulphate reducing bacteria (SRB) which are competitors for the methanogens substrates acetic acid and hydrogen (Bryant et al. 1967; Abram and Nedwell 1978; Chen et al. 2008; Vilela et al. 2014). The SRB is more versatile in the range of substrate used than the methanogens and VFA other than acetic acid, propionic for example, can serve as the substrate for certain species of SRB. Furthermore, the Sulphur 
reduction products, particularly hydrogen sulfide $\left(\mathrm{H}_{2} \mathrm{~S}\right)$, are also inhibitory to methanogenesis (Hulshof et al. 1998; Lens et al. 1998; Chen et al. 2008; Vilela et al. 2014; Camiloti et al. 2014).

Dealing with hydrogen sulphide in the $\mathrm{AD}$ process presents an area of interest to many researchers. Many studies have been conducted to investigate some methods to control sulphate reduction activity in anaerobic digesters to increase methanogenic yield includes $\mathrm{pH}$ adjustment (Visser et al. 1993; Chaiprapat et al. 2011; Moestedt, Paledal and Schnurer 2013), precipitation with iron salts (Zhang, Keller and Yuan 2009), off-gas scrubbing (Ravishanker and Hills 1984; Nisimura and Yoda 1997; Mesa et al. 2002) and using SRB inhibitors, such as sodium nitrite (Nemati et al. 2001; Greene et al. 2003) and molybdate (Nemati et al. 2001; Isa and Anderson 2005).

Sodium molybdate $\left(\mathrm{MoO}_{4}{ }^{2-}\right)$ is a structural analogue of sulphate and known to be an effective inhibitor of sulphate reduction in sediments (Peck 1959; Oremland and Taylor 1978; Nedwell and Banat 1981; Biswas et al. 2009) and it was hypothesised that it could be used to increase methanogenic production from the sulphate-rich waste (Table 1). Additions of $2-20 \mathrm{mM}$ molybdate were sufficient to control the growth of SRB and generation of $\mathrm{H}_{2} \mathrm{~S}$ by SRBs with $85-100 \%$ of inhibition.

It has suggested previously (Peck 1959; Peck 1961; Biswas et al. 2009) that $\mathrm{MoO}_{4}{ }^{2-}$ plays its vital role, as a competitive inhibitor for sulphate in the ATP sulfurylase, by inhibits ATP sulfurylase (the first enzyme in sulphate activation) through the formation of unstable molecule equivalent to adenyl sulphate (APS). The inhibition causes an appropriate electron acceptor has not generated even though energy (ATP) was consumed. Moreover, the addition of molybdate to inoculums confirmed competition for common substrates between the two bacterial groups.

The molybdate stimulates the enhancement of methane production. According to Abraham and Nedwell (1978), the presence of molybdate can inhibit the hydrogen consumption and made it available for hydrogenotrophic methanogen to use it as sources of the electron for $\mathrm{CO}_{2}$ reduction to methane. However, molybdate addition also shows some detrimental effects on methane production. Smith and Klug (1981) shows that high concentration of molybdate $(200 \mathrm{mM})$ can cause $50 \%$ inhibition on methane production. Moreover, Zahedi et al (2014) also found that low concentration of molybdate $(2.5 \mathrm{mM})$ can affect methanogenesis (Table 1).

Table 1.

The use of sodium molybdate in different concentrations to inhibit sulphate reduction.

\begin{tabular}{|c|c|c|c|c|}
\hline Inoculum & $\begin{array}{l}\text { Molybdate } \\
\text { conc. }\end{array}$ & $\begin{array}{l}\% \text { inhibition of } \\
\text { sulphate reduction }\end{array}$ & $\begin{array}{l}\text { \% inhibition of } \\
\text { methane } \\
\text { production }\end{array}$ & Ref. \\
\hline \multirow{4}{*}{ Sediments of a shallow eutrophic lake } & $0.2 \mathrm{mM}$ & 100 & 14 & \multirow{4}{*}{ Smith and Klug, 1981} \\
\hline & $2 \mathrm{mM}$ & 100 & 9 & \\
\hline & $20 \mathrm{mM}$ & 100 & 20 & \\
\hline & $200 \mathrm{mM}$ & ND & 51 & \\
\hline Salt marsh sediment & $20 \mathrm{mM}$ & $96.27 ; 95.09$ & $\mathrm{ND} ; 0$ & $\begin{array}{l}\text { Banat et al. 1981; Nedwell and Banat } \\
\qquad 1981\end{array}$ \\
\hline $\begin{array}{l}\text { Sulphide rich sediment from shallow } \\
\text { coastal lagoon }\end{array}$ & $20 \mathrm{mM}$ & 100 & 0 & Sorensen et al 1981 \\
\hline Waterlogged Alder Swamp & $1-5 \mathrm{mM}$ & 97.43 & 0 & Westermann and Ahring 1987 \\
\hline $\mathrm{AD}$ active sludge & 3 & 100 & 0 & Tanaka and Lee 1997 \\
\hline Active sludge form anaerobic digester & 3 & 100 & 0 & Ranade et al 1999 \\
\hline $\begin{array}{l}\text { Enriched biomass from two-phase } \\
\text { anaerobic digester }\end{array}$ & $2.5 \mathrm{mM}$ & 100 & 50 & Isa and Anderson 2005 \\
\hline SRB enriched biomass from & $3 \mathrm{mM}$ & 85 & 0 & Patidar and Tare 2005 \\
\hline Swine manure slurry & $2 \mathrm{mM}$ & 99.33 & ND & Predicala et al 2008 \\
\hline Anaerobic digester effluent & $2.5 \mathrm{mM}$ & 100 & 11 & Zahedi et al 2014 \\
\hline
\end{tabular}

\section{Microbial structure and dynamics residing in anaerobic digesters}

To optimising energy recovery from $\mathrm{AD}$ process, the microbial system must have stable performance over time although there are various metabolic functions and taxonomic community composition in bioreactors (Werner et al. 2011; Louca et al. 2018). There are three ecological factors that very influential in maintaining a stable and robust community function in bioreactors: (i) functionally diverse microbial community in the sense that there are set of organisms capable of performing each metabolic function based on their genetic content (Werner et al. 2011; Louca et al. 2016; Louca et al. 2018). (ii) Evenness in functional structures (relative abundance of various functional groups of genes that associated with specific biochemical function) of the communities ensures that the microbial system has more capacity to use various pathways to induce methane production (Werner et al. 2011; Rivett and Bell 2018; Louca et al. 2018). Finally, (iii) based on their identical end-products (ex: $\mathrm{CH}_{4}$ and $\mathrm{CO}_{2}$ ), the coexistence of multiple distinct organisms (taxonomically) that exhibit high functional redundancy allow the community to maintain focal function overtime under perturbation and disturbances at a given place and times (Allison and Martiny 2008; Werner et al. 2011; Louca et al., 2018).

Many studies have sequenced and analysed through PCR amplification of conserved marker genes of the most abundant organisms in the anaerobic digesters to understand microbe community composition, but still view information about the dynamics in microbial systems and the influence on maintaining metabolic function and 
process stability (Briones and Raskin 2003; Riviere et al. 2009; Werner et al. 2011; Vanwonterghem et al. 2014).

Microbial community shifts in bioreactors may be shaped by some environmental factors, such as temperature, $\mathrm{pH}$, organic loading rate (OLR), hydraulic retention time (HRT), sulphate, ammonia concentration and feedstock composition (Dollhopf et al. 2001; Rademacher et al. 2012; Franke-Whittle et al. 2014; Li et al. 2015; Langer et al. 2015; Hulsen et al. 2016). Many researchers showed that change in microbial community during $\mathrm{AD}$ process does not affect the biogas production rates (Fernandez et al. 2005; Briones and Raskin 2003; Langer et al. 2015), suggest that functional stability of AD actively controlled by the environment and not the taxonomic variations because the microbial systems carried out focal biochemical functional at similar rates, regardless of differences in composition. A possible reason for this phenomena is alternative microbes can perform the same focal biochemical functions, or there is a functional redundancy (Louca et al. 2018), thus the microbial system better buffered against microbial shift caused by perturbation or disturbance. Several studies indicate the high resilience of microbial communities in diverse anaerobic digesters during $\mathrm{AD}$ through shifts within the microbial community structure, in terms of the species and their abundance, did not impact the biogas production rates. It means that the microbial communities residing in the digester adjust to applied conditions and optimised their metabolism in a way that assure efficient biogas production (Allison and Martiny 2008; Bengelsdorf et al. 2013; Langer et al. 2015).

\section{Conclusion}

Fossil energy is depleted, making the use of green technology increasingly important. The advantage of anaerobic digestion technology is that it can be used as a method for waste management. This is important to say because the process of solid waste disposal and liquid waste treatment requires huge costs, so any technology that can prevent the accumulation of solid material that is disposed of at landfills is very important. Every by-product released from the anaerobic digestion system, called digestate, can be further processed and used as fertilizer because it contains a lot of nitrogen (Bhatiraja et al. 2018), which means it will reduce the use of synthetic fertilizers. Moreover, anaerobic digestion systems are flexible because they can treat various types of waste, which means this technology can be widely applied. Its flexibility includes solid and liquid waste derived from the food and beverage industry (such as milk and beer) and agriculture. Another advantage is the amount of sludge (biomass) produced is far less when compared to aerobic waste treatment (Chen et al. 2008), only requires low nutritional input and relatively low operational and maintenance costs (Wijekoon et al. 2011; De Vrieze et al. 2012 ; NathiaNeves et al. 2018).

The main challenge in the application of this technology is the efficiency and stability of anaerobic digestion which depends on the syntrophic activity of various microorganisms that carry out hydrolysis, acidogenesis, acetogenesis and methanogenesis. Not only the composition of the community and its metabolic functions but also operational conditions (such as the type of feedstocks, $\mathrm{pH}$ and temperature) also influence the microbial system (structure and dynamics) which can be linked to the efficiency and stability of anaerobic digestion process.

\section{Acknowledgements}

Thanks to Indonesian Endowment Fund for Education (LPDP) for the support.

\section{References}

Abram, J.W., and Nedwell, D.B. (1978) Inhibition of methanogenesis by sulphate-reducing bacteria competing for transferred hydrogen. Arch. Microbiol. 117, 89-92. https://doi.org/10.1007/BF00689356

Achinas, S., Achinas, V., dan Euverink, G.J.W. (2017) A technological overview of biogas production from biowaste. Engineering. $\quad 3$ 299-307. https://doi.org/10.1016/J.ENG.2017.03.002

Allison, S.D. and Martiny, J.B.H. (2008) Resistance, resilience, and redundancy in microbial communities. PNAS. 105, 11512-11519. https://doi.org/10.1073/pnas.0801925105

Amani, T., Nosrati, M. \& Sreekrishnan, T.R. (2010) Anaerobic digestion from the viewpoint of microbiological, chemical, and operational aspects - a review. Environ. Rev. 18, 255-278. doi:10.1139/A10-011

Amekan, Y. and Guntoro (2017) Bioethanol production using alginate from Sargassum binderi as an immobilization matrix for Saccharomyces cerevisiae D.01 cells in a batch reactor with circulation. Research Journal of Pharmaceutical, Biological and Chemical Science. 8(2), 1925-1933 http://scholar.google.com/scholar?cluster=1260293999605042 5961\&hl=en\&oi=scholarr

Amekan, Y., Wangi, D.S.A.P., Cahyanto, M.N., Sarto and Widada, J., (2018), Effect of Different Inoculum Combination on Biohydrogen Production from Melon Fruit Waste. Int. Journal of Renewable Energy Development, 7(2), 101-109, doi.org/10.14710/ijred.7.2.101-109

Angelidaki, I., Ahring, B.K., (1993) Thermophilic digestion of livestock waste: the effect of ammonia. Appl. Microbiol. Biotechnol. 38, 560-564. https://doi.org/10.1007/BF00242955

Balk, M., Weijma, J. and Stams, A.J.M. (2002) Thermotoga lettingae sp. nov., a novel thermophilic, methanol-degrading bacterium isolated from a thermophilic anaerobic reactor. Int J Syst Evol Microbiol. 52, 1361-1368. https://doi.org/10.1099/00207713-52-4-1361

Banat, I.M., Lindstrom, E.B., Nedwell, D.B. and Balba M.T. (1981) Evidence for Coexistence of Two Distinct Functional Groups of Sulfate-Reducing Bacteria in Salt Marsh Sediment. Applied and Environmental Microbiology. 42(6): 985-992. https://www.ncbi.nlm.nih.gov/pmc/articles/PMC244143/

Bengelsdorf FR, Gerischer U, Langer S, Zak M, Kazda M. (203) Stability of a biogas-producing bacterial, archaeal and fungal community degrading food residues. FEMS Microbiol Ecol. 84,201-212. doi: 10.1111/1574-6941.12055.

Barredo, M.S., Evison, L.M. (1991) Effect of propionate toxicity on methanogen- enriched sludge, Methanobrevibacter smithii, and Methanospirillum hungatii at different $\mathrm{pH}$ values. Appl Environ Microbiol 57, 1764-1769. https://www.ncbi.nlm.nih.gov/pmc/articles/PMC183465/

Bharathiraja, B., Sudharsana, T., Jayamuthunagai, J., Praveenkumar, R., Chozhavendhan, S., dan Iyyappan, J. (2018) Biogas production - A review on composition, fuel properties, feedstock and principles of anaerobic digestion. Renewable and Sustainable Energy Reviews. 90, 570-582 https://doi.org/10.1016/j.rser.2018.03.093

Biswas, K.C., Woodards, N.A., Xu, H. and Barton, L.L. (2009) Reduction of molybdate by sulfate-reducing bacteria. 
Biometals. 22, 131-139. https://doi.org/10.1007/s10534-0089198-8

Bocher, B.T.W., Cherukuri, K., Maki, J.S. and Zitomer, D.H. (2015) Relating methanogen community structure and anaerobic digester function. Water Research. 70, 425-435. https://doi.org/10.1016/j.watres.2014.12.018

Bond, T., \& Templeton, M.R. (2011) History and future of domestic biogas plants in the developing world. Energy Sustain. Dev. $\quad 15, \quad 347-354$. https://doi.org/10.1016/j.esd.2011.09.003

Boon, F. (1994) Influence of $\mathrm{pH}$, High volatile fatty acids concentrations and partial hydrogen pressure on hydrolysis. MSc Thesis, Wageningen, The Netherlands.

Boone, D.R. (1985) Fermentation reactions of anaerobic digestion. In PN Cheremisinoff and RP Oullette (edn), Biotechnology: applications and research. Technomic Publishing Co., Lancaster, PA. pp. 41-51.

Borja, R., Sanche'z, E., Weiland, P., (1996) Influence of ammonia concentration on thermophilic anaerobic digestion of cattle manure in upflow anaerobic sludge blanket (UASB) reactors. Process Biochem. $31 \quad$ (5), $477-483$. https://doi.org/10.1016/0032-9592(95)00099-2

BPS-Statistics Indonesia (2019) Statistical Yearbook of Indonesia 2019. National Report, BPS-Statistics Indonesia, Jakarta.

Briones, A. and Raskin, L. (2003) Diversity and dynamics of microbial communities in engineered environments and their implications for process stability. Curr Opin Biotechnol. 14(3), 270-276. https://www.ncbi.nlm.nih.gov/pubmed/12849779

Bryant, M.E., Wolin, E.A., Wolin, M.J. and Wolfe, R.S., (1967) Methanobacillus omelianskii, a symbiotic association of two species of bacteria. Arch. Mikrobiol. 59, 20-31. https://doi.org/10.1007/BF00406313

Calusinska, M., Goux, X., Fossepre, M., Muller, E.E.L., Wilmes, P. \& Delfosse, P. (2018) A year of monitoring 20 mesophilic full-scale bioreactors reveals the existence of stable but different core microbiomes in bio-waste and wastewater anaerobic digestion systems. Biotechnology for Biofuels. 11(196), 1-19. https://doi.org/10.1186/s13068-018-1195-8

Camiloti, P.R., Mockaitis, G., Rodrigues, J.A.D., Damianovic, M.H.R.Z., Foresti, E., Zaiat, M. (2014) Innovative anaerobic bioreactor with fixed-structured bed (ABFSB) for simultaneous sulfate reduction and organic matter removal. J. Chem. Technol. Biotechnol. 89, 1044-1050. https://doi.org/10.1002/jctb.4199

Chaiprapat, S., Preechalertmit, P., Boonsawang, P., Karnchanawong, S. (2011) Sulfidogenesis in pretreatment of high-sulfate acidic wastewater using anaerobic sequencing batch reactor and upflow anaerobic sludge blanket reactor. Environ. Eng. Sci. 28, 597-604. https://doi.org/10.1089/ees.2010.0492

Chen, Y., Cheng, J.J., and Creamer, K.S. (2008) Inhibition of anaerobic digestion process: A review. Bioresource Technology. 99(10), https://doi.org/10.1016/j.biortech.2007.01.057

Chen, X., Liu, Y., Peng, L., Yuan, Z., \& Ni, B. J. (2016). ModelBased Feasibility Assessment of Membrane Biofilm Reactor to Achieve Simultaneous Ammonium, Dissolved Methane, and Sulfide Removal from Anaerobic Digestion Liquor. Scientific reports, 6, 25114. doi:10.1038/srep25114

Cirne, D.G., Lehtomäki, A., Björnsson, L. and Blackhall, L.L. (2007) Hydrolysis and microbial community analysis in twostage anaerobic digestion of energy crops. J Appl Microbiol. 103: $\quad 516-527 . \quad$ https://doi.org/10.1111/j.13652672.2006.03270.x

Costa, K.C. and Leigh, J.A. (2014) Metabolic versatility in methanogens. Curr Opin Biotechnol. 29,70-75 https://doi.org/10.1016/j.copbio.2014.02.012

de Baere, L.A., Devocht, M., van Assche, P., Verstraete, W. (1984) Influence of high $\mathrm{NaCl}$ and $\mathrm{NH}_{4} \mathrm{Cl}$ salt levels on methanogenic associations. Water Res. 18, 543-548. https://doi.org/10.1016/0043-1354(84)90201-X de Bok, F.A., Stams, A.J., Dijkema, C. and Boone, D.R. (2001) Pathway of propionate oxidation by a syntrophic culture of Smithella propionica and Methanospirillum hungatei. Appl $\begin{array}{lll}\text { Environ } & \text { Microbiol 67,1800-1804. DOI: }\end{array}$ 10.1128/AEM.67.4.1800-1804.2001

de Bok, F.A.M., Harmsen, H.J.M., Plugge, C.M., de Vries, M.C., Akkermans, A.D.L., de Vos, W.M., and Stams, A.J.M. (2005) The first true obligately syntrophic propionate oxidizing bacterium, Pelotomaculum schinkii sp. nov., co-cultured with Methanospirillum hungatei, and emended description of the genus Pelotomaculum. International Journal of Systematic and Evolutionary Microbiology 55, 1697-1703. https://doi.org/10.1099/ijs.0.02880-0

de Jonge, N., Moset, V., Møller, H.B., Nielsen, J.L. (2017) Microbial population dynamics in continuous anaerobic digester systems during start up, stable conditions and recovery after starvation. Bioresour.Technol. 232, 313-320. doi:10.1016/j.biortech.2017.02.036

Demirel, B. and Yenigün, O. (2002) The effects of change in volatile fatty acid (VFA) composition on methanogenic upflow filter reactor (UFAF) performance. Environ Technol 23: 11791187. https://doi.org/10.1080/09593332308618336

De Vrieze, J., Saunders, A.M., Hey, Y., Fang, J., Nielsen, P.H., Verstraete, W., and Boon, N. (2015) Ammonia and temperature determine potential clustering in the anaerobic digestion microbiome. Water Res. 75, 312-323. https://doi.org/10.1016/j.watres.2015.02.025

De Vrieze, J., Christiaens, M.E.R., Walraedt, D., Devooght, A., Ijaz, U.Z., and Boon, N. (2017) Microbial community redundancy in anaerobic digestion drives process recovery after salinity exposure. Water Research 11, 109-117. https://doi.org/10.1016/j.watres.2016.12.042

De Vrieze, J., Pinto, A.J., Sloan, W.T., and Ijaz, U.Z. (2018) The active microbial community more accurately reflects the anaerobic digestion process: 16s rRNA (gene) sequencing as a

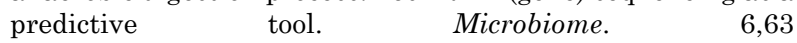
https://doi.org/10.1186/s40168-018-0449-9

Diaz, A.I., Oulego, P., Collado, S., Laca, A., Gonzalez, J.M. \& Diaz, M. (2018) Impact of anaerobic digestion and centrifugation/decanting process in bacterial communities fractions. Journal of Bioscience and Bioengineering. 126(6), 742-749. https://doi.org/10.1016/j.jbiosc.2018.05.024

Dokulilova, T., Koutny, T., and Vitez, T. (2018) Effect of zinc and copper on anaerobic stabilization of sewage sludge. Acta Universitatis Agriculturae et Silviculturae Mendelianae Brunensis. 66(2), 357-363. https://doi.org/10.11118/actaun201866020357

Dollhopf, S., Hashsham, S., Dazzo, F., Hickey, R., Criddle, C. and Tiedje, J. (2001) The impact of fermentative organisms on carbon flow in methanogenic systems under constant lowsubstrate conditions. Appl Microbiol Biotechnol. 56: 531. https://doi.org/10.1007/s002530100612

Dong, X., Xin, Y., Jian, W., Liu, X. and Ling, D. (2000). Bifidobacterium thermacidophilum sp. nov., isolated from an anaerobic digester. Int J Syst Evol Microbiol 50, 119-125. https://doi.org/10.1099/00207713-50-1-119

EBTKE (2016) Statistik EBTKE 2016. National Report, Directorate General of New, Renewable Energy and Energy Conservation, Jakarta

Fernandez, A., Sanchez, A. and Font, X. (2005) Anaerobic codigestion of a simulated organic fraction of municipal solid wastes and fats of animal and vegetable origin. Biochemical Engineering Journal. 26(1), 22-28. https://doi.org/10.1016/j.bej.2005.02.018

Ferry, J.G. (2002) Methanogenesis biochemistry. Encyclopedia of Life Sciences. $1-9$ https://onlinelibrary.wiley.com/doi/10.1038/npg.els.0000573

Fournier, G.P. and Gogarten, J.P. (2008) Evolution of acetoclastic methanogenesis in Methanosarcina via horizontal gene transfer from cellulolytic Clostridia. Journal of Bacteriology. 190(3), 1124-1127. https://doi.org/10.1128/JB.01382-07 
Francisci, D. D., Kougias, P. G., Treu, L., Campanaro, S., and Angelidaki, I. (2015) Microbial diversity and dynamicity of biogas reactors due to radical changes of feedstock composition. Bioresource Technology. 176, 56-64. https://doi.org/10.1016/j.biortech.2014.10.126

Franke-Whittle, I.H., Walter, A., Ebner, C. and Insam, H. (2014) Investigation into the effect of high concentrations of volatile fatty acids in anaerobic digestion on methanogenic communities. Waste Management. 34(11), 2080-2089. https://doi.org/10.1016/j.wasman.2014.07.020

Gallert, C., Bauer, S., Winter, J. (1998) Effect of ammonia on the anaerobic degradation of protein by a mesophilic and thermophilic biowaste population. Appl. Microbiol. Biotechnol. 50, 495-501. https://www.ncbi.nlm.nih.gov/pubmed/9830101

Gerardi, M.H. (2003) The microbiology of anaerobic digesters. John Wiley \& Sons, Inc. DOI:10.1002/0471468967

Greene E. A., Hubert C., Nemati M., Jenneman G. E., Voordouw G. (2003). Nitrite reductase activity of sulphate-reducing bacteria prevents their inhibition by nitrate-reducing, sulphide-oxidizing bacteria. Environ. Microbiol. 5, 607-617. 10.1046/j.1462-2920.2003.00446.x

Guneratnam, A.J., Ahern, E., FitzGerald, J.A., Jackson, S.A., Xia, A., Dobson, A.D.W., Murphy, J.D., (2017). Study of the performance of a thermophilic biological methanation system.

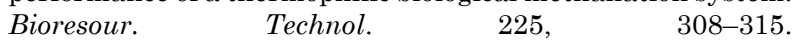
http://dx.doi.org/10.1016/j.biortech.2016.11.066

Hardegen, J., Latorre-Perez, A., Vilanova, C., Gunther, T., Simeonov, C., Porcar, M., LuLuschnig, O., Abendroth, C., (2018) Liquid co-substrates repower sewage microbiomes. Biorxiv. doi: http://dx.doi.org/10.1101/261339

Hassa, J., Maus, I., Off, S., Puhler, A., Scherer, P., Klocke, M., and Schluter, A. (2018) Metagenome, metatranscriptome, and metaproteome approaches unravelled compositions and functional relationships of microbial communities residing in biogas plants. Appl. Microbiol. Biotechnol. 102(12), 50455063. https://doi.org/10.1007/s00253-018-8976-7

Heeg, K., Pohl, M., Sontag, M., Mumme, M., Klocke, M. \& Nettmann E. (2014) Microbial communities involved in biogas production from wheat straw as the sole substrate within a two-phase solid-state anaerobic digestion. Systematic and Applied Microbiology. 37(8), 590-600. https://doi.org/10.1016/j.syapm.2014.10.002

Henderson, P.J.F. (1971) Ion Transport by energy-conserving Biological Membranes. Annual Review of Microbiology. 25, 393-428.

https://doi.org/10.1146/annurev.mi.25.100171.002141

Hilton, M.G., and Archer, D.B. (1988) Anaerobic digestion of a sulfate-rich molasses wastewater: inhibition of hydrogen sulphide production. Biotechnology and Bioengineering 31, 885-888. https://doi.org/10.1002/bit.260310817

Hulsen T., Barry, E.M., Lu, Y., Puyol, D. and Batstone, D.J. (2016) Low temperature treatment of domestic wastewater by purple phototrophic bacteria: Performance, activity, and community. Water Research. 100, 537-545. https://doi.org/10.1016/j.watres.2016.05.054

Hulshoff Pol, L.W., Lens, P.N.L., Stams, A.J.M., and Lettinga, G., (1998) Anaerobic treatment of sulphate-rich wastewaters. Biodegradation.

9 , https://doi.org/10.1023/A:1008307929134

Imachi, H., Sakai, S., Ohashi, A., Harada, H., Hanada, S., Kamagata, Y. and Sekiguchi, Y. (2007) Pelotomaculum propionicicum sp. nov., an anaerobic, mesophilic, obligately syntrophic, propionate-oxidizing bacterium. Int J Syst Evol Microbiol 57, 1487-1492. https://doi.org/10.1099/ijs.0.64925-0

Insam, H., Franke-Whittle, I., and Goberna, M. (2010) Microbes at Work: from waste to resources. Springer-Verlag Berlin Heidelberg.

Isa, M.H. and Anderson, G.K. (2005) Molybdate inhibition of sulphate reduction in two-phase anaerobic digestion. Process
Biochemistry.

40(6),

2079-2089.

https://doi.org/10.1016/j.procbio.2004.07.025

Jackson, B.E., Bhupathiraju, V.K., Tanner, R.S., Woese, C.R. and McInerney, M.J. (1999) Syntrophus aciditrophicus sp. nov., a new anaerobic bacterium that degrades fatty acids and benzoate in syntrophic association with hydrogen-using microorganisms. Arch Microbiol 171, 107-114. https://doi.org/10.1007/s002030050685

Jarrell, K.F., Saulnier, M., Ley, A., (1987) Inhibition of methanogenesis in pure cultures by ammonia, fatty acids, and heavy metals, and protection against heavy metal toxicity by sewage sludge. Can. J. Microbiol. 33, 551-555. https://doi.org/10.1139/m87-093

Kim, M.S., Kim, D.H., Yun, Y.M. (2017) Effect of operation temperature on anaerobic digestion of food waste: performance and microbial analysis. Fuel. 209, 598-605. https://doi.org/10.1016/j.fuel.2017.08.033

Kirkegaard, R.H., McIlroy, S.J., Kristensen, J.M., Nierychlo, M., Karst, S.M., Duelhom, M.S., Albertsen, M., and Nielsen, P.H., (2017) The impact of immigration on microbial community composition in full-scale anaerobic digesters. Scientific Reports 7, 9343. https://doi.org/10.1038/s41598-017-09303-0

Koster, I.W., Lettinga, G., (1988) Anaerobic digestion at extreme ammonia concentrations. Biol. Wastes 25, 51-59. https://doi.org/10.1016/0269-7483(88)90127-9

Kroeker, E.J., Schulte, D.D., Sparling, A.B., Lapp, H.M. (1979) Anaerobic treatment process stability. J. Water Pollut. $\begin{array}{lllll}\text { Control } & \text { Fed. } & 51, & 718- & 727 .\end{array}$ https://www.jstor.org/stable/25039893

Langer, S.G., Ahmed, S., Einfalt, D., Bangelsdorf, F.R., and Kazda, M. (2015) Functionally redundant but dissimilar microbial communities within biogas reactors treating maize silage in co-fermentation with sugar beet silage. Microb Biotechnol. 8(5), 828-836. https://doi.org/10.1111/17517915.12308

Lens, P.N.L., Visser, A., Janssen, A.J.H., Hulshoff Pol, L.W., Letingga, G. (1998) Biotechnological treatment of sulfate-rich wastewaters. Crit. Rev. Env. Sci. Tec. 28 (1), 41-88. https://doi.org/10.1080/10643389891254160

Li, J., Rui, J., Yao, M., Zhang, S., Yan, X., Wang, Y., Yan, Z., Li, X. (2015) Substrate Type and Free Ammonia Determine Bacterial Community Structure in Full-Scale Mesophilic Anaerobic Digesters Treating Cattle or Swine Manure. $\begin{array}{llll}\text { Frontiers in microbiology, } & 6, & 1337 .\end{array}$ doi:10.3389/fmicb.2015.01337

Liebl, W. (2001) Cellulolytic enzymes from Thermotoga species. Methods $\quad$ Enzymol. $\quad 330: \quad 290-300$. https://doi.org/10.1016/S0076-6879(01)30383-X

Liu, Y., Balkwill, D.L., Aldrich, H.C., Drake, G.R. and Boone, D.R. (1999) Characterization of the anaerobic propionatedegrading syntrophs Smithella propionica gen. nov., sp. nov. and Syntrophobacter wolinii. Int J Syst Bacteriol 49, 545-556. https://www.ncbi.nlm.nih.gov/pubmed/10319475

Liu, T., Sung, S., (2002) Ammonia inhibition on thermophilic aceticlastic methanogens. Water Sci. Technol. 45, 113-120. https://www.ncbi.nlm.nih.gov/pubmed/12188530

Liu, Y., Beer, L.L., and Whitman, W.B. (2012) Methanogens: a window into ancient sulphur metabolism. Trends in Microbiology. 20(5), 251-258 https://doi.org/10.1016/j.tim.2012.02.002

Louca, S., Hawley, A.K., Katsev, S., Torres-Beltran, M., Bhatia, M.P., Kheirandish, S., Michiels, C.C., Capelle, D., Lavik, G., Doebeli, M., Crowe, S.A. and Hallam, S.J. (2016) Integrating biogeochemistry with multiomic sequence information in a model oxygen minimum zone. Proc. Natl Acad. Sci. USA 113, E5925-E5933. https://doi.org/10.1073/pnas.1602897113

Louca, S., Polz, M.F., Mazel, F., Albright, M.B.N., Huber, J.A., O'connor, M.I., Ackermann, M., Hahn, A.S., Srivastava, D.S., Crowe, S.A., Doebeli, M., and Parfrey, L.W. (2018) Function and functional redundancy in microbial systems. Nature 
Ecology \& Evolution 2, 936-943. https://doi.org/10.1038/s41559-018-0519-1

Lowe, S.E., Jain, M.K. and Zeikus, J.G. (1993) Biology, ecology, and biotechnological applications of anaerobic bacteria adapted to environmental stresses in temperature, $\mathrm{pH}$, salinity, or substrates. Microbiol Rev 57, 451-509. https://www.ncbi.nlm.nih.gov/pmc/articles/PMC372919/

McCarty, P.L., 1964. Anaerobic waste treatment fundamentals. Public Works 95 (9), 107-112.

McCarty, P.L. and Smith, D.P. (1986) Anaerobic wastewater treatment. Environ Sci Technol 20: 1200-1206. https://doi.org/10.1021/es00154a002

Mesa, M. M., M. Macías and D. Cantero. (2002) Biological iron oxidation by Acidithiobacillus ferrooxidans in packed-bed bioreactor. Chemical and Biochemical Engineering Quarterly 16(2):

69-73. http://citeseerx.ist.psu.edu/viewdoc/download?doi=10.1.1.320 $.5576 \&$ rep $=$ rep $1 \&$ type $=$ pdf

Moestedt, J., Paledal, S.N. and Schnurer, A. (2013). The effect of substrate and operational parameters on the abundance of sulphate-reducing bacteria in industrial anaerobic biogas digesters. Bioresource Technology. 132, 327-332. http://dx.doi.org/10.1016/j.biortech.2013.01.043

Montañés, R., Pérez, M., Solera, R. (2014) Anaerobic mesophilic co-digestion of sewage sludge and sugar beet pulp lixiviation in batch reactors: effect of pH control. Chem Eng J 255:492499. https://doi.org/10.1016/j.cej.2014.06.074

Nathia-Neves, G., Berni, M., Dragone, G., Mussatto, S.I. \& Forster-Carneiro, T. (2018) Anaerobic digestion process: technological aspects and recent developments. International Journal of Environmental Science and Technology. https://doi.org/10.1007/s13762-018-1682-2

Nedwell, D.B., and Banat, I.M. (1981) Hydrogen as an Electron donor for sulfate-reducing bacteria in slurries of salt marsh sediment. Microb. Ecol. 7, 305-313. https://doi.org/10.1007/BF02341425

Nelson, M.C., Morrison, M. and Yu, Z. (2011) A meta-analysis of the microbial diversity observed in anaerobic digesters. Bioresour Technol. $\quad 102(4), \quad 3730-3739$. https://doi.org/10.1016/j.biortech.2010.11.119

Nemati, M., Mazutinec, T.J., Jenneman, G.E. and Voordouw, G. (2001) Control of biogenic $\mathrm{H}_{2} \mathrm{~S}$ production with nitrite and molybdate. Journal of Industrial Microbiology and Biotechnology. 26(6), 350-355 https://doi.org/10.1038/sj.jim.7000142

Nielsen, H.B., Uellendahla, H. and Ahring, B.K., 2007. Regulation and optimization of the biogas process: propionate as a key parameter. Biomass and Bioenergy 31, 820-830. https://doi.org/10.1016/j.biombioe.2007.04.004

Nisimura, S. and Yoda, M. (1997) Removal of hydrogen sulphide from an anaerobic biogas using a bio-scrubber. Water Science and Technology. 36(6-7), 349-356. https://doi.org/10.1016/S0273-1223(97)00542-8

Oremland, R. S., and Taylor, B. F. (1978) Sulfate reduction and methanogenesis in marine sediments. Geoehim, Cosmochim. 42, 209-214. https://doi.org/10.1016/0016-7037(78)90133-3

O`Sullivan, C.A., Burrell, P.C., Clarke, W.P. dan Blackall, L.L. (2005) Structure of a cellulose degrading bacterial community during anaerobic digestion. Biotechnol Bioeng. 92: 871-878. https://doi.org/10.1002/bit.20669

Patidar, S.K. and Tare, V. (2005) Effect of molybdate on methanogenic and sulphidogenic activity biomass. Bioresour Technol. 96(11)1215-1222. https://doi.org/10.1016/j.biortech.2004.11.001

Peck, H. D. (1959) The ATP-dependent reduction of sulfate with hydrogen in extracts of Desulfovibrio desulfuricans. Proc. Nat. Acad. Sci, U.S.A. 45, 701-708. https://dx.doi.org/10.1073\%2Fpnas.45.5.701

Peck, H.D. (1961) Enzymatic basis for assimilatory and dissimilatory sulfate reduction. J. Bacteriol. 82,933-939. https://www.ncbi.nlm.nih.gov/pmc/articles/PMC279279/
Plugge, C.M., 2017. Biogas. Microbial Biotechnology 10(5), 11281130. https://doi.org/10.1111/1751-7915.12854

Pullammanappallil, P.C., Svoronos, S.A., Chynoweth, D.P. and Lyberatos, G. (1998) Expert system for control of anaerobic digesters. Biotech Bioeng 58: 13-22. https://www.ncbi.nlm.nih.gov/pubmed/10099257

Predicala, B., Nemati, M., Stade, S. and Lague, C. (2008) Control of $\mathrm{H} 2 \mathrm{~S}$ emission from swine manure using Na-nitrite and Namolybdate. J Hazard Mater. 154(1-3):300-309. https://doi.org/10.1016/j.jhazmat.2007.10.026

Procházka, J.; Dolejs, P.; Maca, J.; Dohanyos, M. (2012) Stability and inhibition of anaerobic processes caused by insufficiency or excess of ammonia nitrogen. Applied Microbiology Biotechnology 93: 439-47 https://doi.org/10.1007/s00253-0113625-4

Rademacher, A., Zakrzewski, M., Schluter, A, Schonberg, M., Szczepanowski R., Goesmann, A., Puhler, A. and Klocke, M. (2012) Characterization of microbial biofilms in a thermophilic biogas system by high-throughput metagenome sequencing. FEMS Microbiology Ecology. 79(3), 785-799. https://doi.org/10.1111/j.1574-6941.2011.01265.x

Rajagopal, R., Massé, D.I., Singh, G. (2013) A critical review on inhibition of anaerobic digestion process by excess ammonia. Bioresour. Technol. 143, 632-641. https://doi.org/10.1016/j.biortech.2013.06.030

Ranade, D.R., Dighe, A.S., Bhirangi, S.S., Panhalkar, V.S. and Yeole, T.Y. (1999). Evaluation of the use of sodium molybdate to inhibit sulphate reduction during anaerobic digestion of distillery waste. Bioresource Technology. 68(3):287-291. https://doi.org/10.1016/S0960-8524(98)00149-7

Ravishanker, P. and Hills, D. (1984) Hydrogen sulphide removal from anaerobic digester gas. Agricultural Wates. 11(3), 167179. https://doi.org/10.1016/0141-4607(84)90043-X

Regueiro, L., Carballa, M., Lema, J.M. (2014) Outlining microbial community dynamics during temperature drop and subsequent recovery period in anaerobic co-digestion systems. J. Biotechnol. 192, 179-186. doi:10.1016/j.jbiotec.2014.10.007

Rivett, D.W. and Bell, T. (2018) Abundance determines the functional role of bacterial phylotypes in complex communities. Nature Microbiology. 3, 767-772 https://doi.org/10.1038/s41564-018-018-0

Riviere, D., Desvignes, V., Pelletier, E., Chaussonnerie, S., Guermazi, S., Weissenbach, J., Li, T., Camacho, P., and Sghir, A. (2009) Towards the definition of a core of microorganisms involved in anaerobic digestion of sludge. ISME J. 3(6), 700714. https://doi.org/10.1038/ismej.2009.2

Schink, B. (1997) Energetics of syntrophic cooperation in methanogenic degradation. Microbiol Mol Biol Rev 61(2), 262280. https://www.ncbi.nlm.nih.gov/pmc/articles/PMC232610/

Schnurer, A., Zellner, G., and Svensson, B.H. (1999) Mesophilic syntrophic acetate oxidation during methane formation in biogas reactor. FEMS Microbiol. Ecol. 29, 249-261. https://doi.org/10.1016/S0168-6496(99)00016-1

Siles, J.A., Brekelmans, J., Martin, M.A., Chica, A.F., and Martin, A. (2010) Impact of ammonia and sulphate concentration on thermophilic anaerobic digestion. Bioresour. Technol. 101(23),9040-9048. https://doi.org/10.1016/j.biortech.2010.06.163

Sorensen, J., Christensen, D. Jorgensen, B.B. (1981) Volatile Fatty acids and hydrogen as substrates for sulfate-reducing bacteria in anaerobic marine sediment. Appl Environ Microbiol. https://www.ncbi.nlm.nih.gov/pmc/articles/PMC243952/

Sousa, D.Z., Smidt, H., Alves, M.M. and Stams, A.J. (2007) Syntrophomonas zehnderi sp. nov., an anaerobe that degrades long-chain fatty acids in co-culture with Methanobacterium formicicum. Int J Syst Evol Microbiol 57, 609-615. https://doi.org/10.1099/ijs.0.64734-0

Sousa, D. Z., Salvador, A. F., Ramos, J., Guedes, A. P., Barbosa, S., Stams, A. J., ... Pereira, M. A. (2013) Activity and viability of methanogens in anaerobic digestion of unsaturated and 
saturated long-chain fatty acids. Applied and environmental microbiology, 79(14), 4239-4245. doi:10.1128/AEM.00035-13

Smith, R.L., and Klug, M.J. (1981) Electron donors utilized by sulfate-reducing bacteria in eutrophic lake sediments. Appl Environ Microbiol. $\quad 42(1)$ : 116-121 https://www.ncbi.nlm.nih.gov/pmc/articles/PMC243972/

Speece, R.E., Boonyakitsombut, S., Kim, M., Azbar, N. dan Ursillo, P. (2006) Overview of anaerobic treatment: thermophilic and propionate implications. Water Environ Res 78: 460-473. https://doi.org/10.2175/106143006X95492

Stams, A.J. and Plugge, C.M. (2009) Electron transfer in syntrophic communities of anaerobic bacteria and archaea. $\begin{array}{lllll}\text { Nat } & \text { Rev } & \text { Microbiol } & \text { 7: } & \text { 568-577. }\end{array}$ https://doi.org/10.1038/nrmicro2166

Stiles, M.E. and Holzapfel, W.H. (1997) Lactic acid bacteria of foods and their current taxonomy. Int J Food Microbiol. 36: 129. https://doi.org/10.1016/s0168-1605(96)01233-0

Sträuber, H., Schröder, M. and Kleinsteuber, S. (2012) Metabolic and microbial community dynamics during the hydrolytic and acidogenic fermentation in a leach-bed process. Energ Sustain Soc. 2: 13. https://doi.org/10.1186/2192-0567-2-13

Sung, S., Liu, T., (2003) Ammonia inhibition on thermophilic digestion. Chemosphere 53, 43-52. https://doi.org/10.1016/S0045-6535(03)00434-X

Talbot, G., Topp, E., Palin, M.F., and Massé, D. (2008) Evaluation of molecular methods used for establishing the interactions and functions of microorganisms in anaerobic bioreactors. Water research. $42, \quad 513-537$. https://doi.org/10.1016/j.watres.2007.08.003

Tanaka, S. and Lee, Y. (1997) control of sulfate reduction by molybdate in anaerobic digestion. Water science and technology. 36(12):143-150. https://doi.org/10.1016/S02731223(97)00714-2

Thauer, R.K., Kaster, A.K., Seedorf, H., Buckel, W., and Hedderich, R., 2008. Methanogenic archaea: ecologically relevant differences in energy conservation. Nat. Rev. Microbiol. 6(8), 579-591. https://doi.org/10.1038/nrmicro1931

Van Lier, J.B. (1995) Thermophilic anaerobic wastewater treatment: temperature aspects and process stability. $\mathrm{PhD}$ Thesis. Wageningen Agricultural University, Wageningen, The Netherlands. https://library.wur.nl/WebQuery/wda/abstract/915507

Vanwonterghem, I., Jensen, P.D., Ho, D.P., Bastone, D.J., and Tyson, G.W. (2014) Linking microbial community structure, interactions and function in anaerobic digesters using new molecular techniques. Curr. Opin. Biotechnol. 27, 55-64 doi: 10.1016/j.copbio.2013.11.004.

Vilela, R.S., Damianovic, M.H.R.Z., Foresti, E. (2014) Removing organic matter from sulfate0rich wastewater via sulfidogenic and methanogenic pathways. Water Sci. Technol. 69, 848-853. https://doi.org/10.2166/wst.2014.066

Visser, A., Alphenaar, P.A., Gao, Y., van Rossum, G., and Lettinga, G. (1993) Granulation and immobilisation of methanogenic and sulfate-reducing bacteria in high-rate anaerobic reactors. Appl Microbiol Biotechnol 40, 575. https://doi.org/10.1007/BF00175750

Welte, C. and Deppenmeier, U. (2014) Bioenergetics and anaerobic respiratory chains of acetoclastic methanogens. Biochimica et Biophysica Acta (BBA)-Bioenergetics. 1837(7), 1130-1147. https://doi.org/10.1016/j.bbabio.2013.12.002

Werner, J.J., Knights, D., Garcia, M.L., Scalfone, N.B., Smith, S., Yarasheski, K., Cummings, T.A., Beers,A.R., Knight, R., and Angenent, L.T. (2011) Bacterial community structures are unique and resilient in full-scale bioenergy systems. PNAS 108(10), 4158-4163. https://doi.org/10.1073/pnas.1015676108

Westermann, P. and Ahring, B.K. (1987) dynamics of methane production, sulfate reduction and denitrification in a permanently waterlogged alder swamp. Applied and Environmental Microbiology. 53(10): 2554-2559. https://aem.asm.org/content/53/10/2554

Whittmann, C., Zeng, A.P., Deckwer, W.D. (1995) Growth inhibition by ammonia and use of $\mathrm{pH}$ controlled feeding strategy for the effective cultivation of Mycobacterium chlorophenolicum. Appl. Microbiol. Biotechnol. 44, 519-525. https://doi.org/10.1007/BF00169954

Wilins, D., Rao, S., Lu, X., and Lee, P.K.H. (2015). Effects of sludge inoculum and organic feedstock on active microbial communities and methane yield during anaerobic digestion. Front Microbiol. $\quad 6,1114$. https://dx.doi.org/10.3389\%2Ffmicb.2015.01114

Wirth, R., Kovacs, E., Maroti, G., Bagi, Z., Rakhely, G., \& Kovacs, K.L. (2012) Characterization of a biogas-producing microbial community by short-read next generation DNA sequencing. Biotechnology for Biofuels 5, 41 https://doi.org/10.1186/17546834-5-41

Yamada, T., Sekiguchi, Y., Hanada, S., Imachi, H., Ohashi, A., Harada, H. and Kamagata, Y. (2006) Anaerolinea thermolimosa sp. nov., Levilinea saccharolytica gen. nov., sp. nov. And Leptolinea tardivitalis gen. nov., sp. nov., novel filamentous anaerobes, and description of the new classes Anaerolineae classis nov. and Caldilineae classis nov. in the bacterial phylum Chloroflexi. Int J Syst Evol Microbiol 56, 1331-1340. https://doi.org/10.1099/ijs.0.64169-0

Yu, Z., and Mohan, W.W. (2001) Bacterial diversity and community structure in an aerated lagoon revealed by ribosomal intergenic spacer analyses and $16 \mathrm{~S}$ ribosomal DNA sequencing. Appl. Environ. Microbiol. 67: 1565-1574. https://doi.org/10.1128/AEM.67.4.1565-1574.2001

Zabranska, J. and Pokorna, D. (2018) Bioconversion of carbon dioxide to methane using hydrogen and hydrogenotrophic methanogens. Biotechnol Adv. 36(3), 707-720. https://doi.org/10.1016/j.biotechadv.2017.12.003

Zahedi, S., Sales, D., Romero, L. and Solera, R. (2014) Biomethanization from sulfate-containing municipal solid waste: effect of molybdate on microbial consortium. Journal of Chemical Technology and Biotechnology. 89(9):1379-1387. https://doi.org/10.1002/jctb.4215

Zhang, L., Keller, J. and Yuan, Z. (2009) Inhibition of sulfatereducing and methanogenic activities of anaerobic sewer biofilms by ferric iron dosing. Water Research. 43(17), 41234132. https://doi.org/10.1016/j.watres.2009.06.013

Zhang, Q., Hu, J., \& Lee, D. (2016) Biogas from anaerobic digestion processes: Research updates. Renewable Energy. 98, 108-119. http://dx.doi.org/10.1016/j.renene.2016.02.029

Zhao, J., Liu, Y., Wang, D., Li, X., Zeng, G., \& Yang, Q. (2017). Potential impact of salinity on methane production from food waste anaerobic digestion. Waste Manag. 67, 308-314. https://doi.org/10.1016/j.wasman.2017.05.016

Zverlov, V.V., Hiegl, W., Köck, D.E., Kellermann, J., Köllmeier, T. and Schwarz, W.H. (2010) Hydrolytic bacteria in mesophilic and thermophilic degradation of plant biomass. Eng Life Sci. 10: 528-536. https://doi.org/10.1002/elsc.201000059 